\title{
First microsatellite markers for Paspalum plicatulum (Poaceae) characterization and cross-amplification in different Paspalum species of the Plicatula group
}

\author{
Fernanda A. Oliveira', Fernanda W. Cidade ${ }^{1}$, Alessandra P. Fávero ${ }^{2}$, Bianca B. Z. Vigna ${ }^{2}$ and Anete P. Souza ${ }^{1,3^{*}}$
}

\begin{abstract}
Background: Paspalum plicatulum is a perennial rhizomatous grass with natural diploid and polyploid cytotypes. It is a member of Plicatula, which has historically been recognized as a highly complex group containing species of ecological, ornamental and forage importance. The complex nature of the P. plicatulum genome makes it a challenging species for genetic research. This study aimed to develop and characterize microsatellite molecular markers in $P$. plicatulum and to evaluate their transferability to other Plicatula group species.

Findings: Microsatellite sequences were identified from three enriched libraries from P. plicatulum. Specific primers were designed, and 25 displayed polymorphism when screened across 48 polyploid Paspalum spp. genotypes. The number of bands per locus ranged from 2 to 17, with a mean of 8.65. Private bands for each species were identified; the highest number of private bands was observed for P. plicatulum in 52\% of the loci analyzed. The mean polymorphism information content of all loci was 0.69 , and the mean discriminatory power was 0.82 . Microsatellite markers were satisfactorily cross-amplified for the eight tested Plicatula-group Paspalum species, with P. atratum exhibiting the highest transferability rate (89.86\%). STRUCTURE and Discriminant Analysis of Principal Components separated accessions into three groups but did not reveal separation of the accessions according to species.

Conclusions: This study describes the first microsatellite markers in P. plicatulum, which are polymorphic, efficient for the detection and quantification of genetic variation, and show high transferability into other species of the Plicatula group. This set of markers can be used in future genetic and molecular studies necessary for the proper development of conservation and breeding programs. Private bands within the markers can be used to assist in species identification.
\end{abstract}

Keywords: Paspalum botanical group, Germplasm evaluation, Microsatellite, SSR transferability, Forage, Grass

\section{Background}

The genus Paspalum L. includes approximately 350 species distributed in tropical and subtropical regions. Most of the species are native to South America [1, 2], including 210 species of Brazilian origin [3]. The basic chromosome number in Paspalum is $\mathrm{x}=10$ [4-6]; this number

\footnotetext{
*Correspondence: anete@unicamp.br

${ }^{1}$ Center for Molecular Biology and Genetic Engineering (CBMEG), University of Campinas (UNICAMP), Cidade Universitária Zeferino Vaz, CP 6010, Campinas, SP CEP 13083-970, Brazil

Full list of author information is available at the end of the article
}

is the most common, with a few exceptions. Polyploidy is present in nearly $80 \%$ of the species [2], with tetraploidy being the most frequent condition (ca. 50\%) [7-9], although diploids have also been found in the genus [1, 10]. Generally, species of Paspalum consist of sexual-diploid and apomictic-polyploid cytotypes [11].

Among the Paspalum species, our efforts are dedicated to the study of Paspalum plicatulum Michx., a perennial rhizomatous grass with natural diploid and polyploid cytotypes [12]. This grass originated in Brazil and is widely distributed from the southern United States 
to southern Argentina and Western India. This species has ecological, ornamental and forage importance [13] and is known as "pasto negro" in Brazil as it is generally used in pastures. Paspalum plicatulum is member of the Plicatula group, which represents species that occur throughout the Brazilian territory with wide morphological variation [14].

The Plicatula group is an informal botanic group proposed by Chase [15] to group species related to P. plicatulum. The group is easily differentiated by the morphology of the spikelet, which has sterile lemma with transverse wrinkles and a conspicuously convex anthecium and is a shining dark brown. However, the variability of reproductive and vegetative characters makes identification at the specific level difficult. As such, several species and accessions have been included in this group as synonyms for P. plicatulum [1]. The lack of correct characterization of the members of this group and the quantification of their variability make it difficult to use them in breeding and conservation programs and in germplasm exchanges. Although some studies have been reported with germplasm banks and taxonomic revisions of this group, many species of the group Plicatula remain unidentified [16, 17].

The complex nature of the P. plicatulum genome makes the species a challenging target for genetic research. Thus, our goal in this study was to develop specific microsatellite markers for $P$. plicatulum. Variation of molecular markers specifically developed for the species serves as a powerful tool for the identification of individuals. Furthermore, these markers can potentially provide an excellent tool for the study of the Plicatula group species, aiding in botanical species classification. For this purpose, we isolated and characterized microsatellite markers from $P$. plicatulum and evaluated the transferability of these markers in Paspalum species belonging to the Plicatula group.

\section{Methods}

\section{Plant material and DNA extraction}

Three accessions of $P$. plicatulum, BGP 8 , BGP 80 and BGP 86 (collector code-V 5852), were chosen randomly for library construction. For characterizing loci, fortyeight Paspalum accessions from different species belonging to the Plicatula group were evaluated (Table 1), among which were included two (BGP 8, BGP 80) of the three samples used for the library construction. These samples are from the Germplasm Bank of Paspalum, maintained by EMBRAPA Southeast Livestock, São Carlos, SP, Brazil, and were originally collected from the south to the north of Brazil. Twenty-six samples are from P. plicatulum, and the other 27 accessions were used for evaluation of transferability and correspond to the following species: 3 from $P$. atratum Swallen; 4 from $P$. compressifolium Swallen; 6 from P. guenoarum Arechav., P. lenticulare Kunth. and P. rhodopedum L.B.Sm. and Wassh. (3); one from P. lepton Schult.; and two from $P$. rojasii Hack. Total genomic DNA samples were extracted from lyophilized leaf tissues following the cetyltrimethylammonium bromide (CTAB) method, previously described by [18], and DNA quality and quantity were assessed using $1 \%$ agarose gel electrophoresis, with comparison to known quantities of uncut $\kappa$ phage DNA (Invitrogen, Carlsbad, CA, USA).

\section{Construction of microsatellite-enriched libraries and sequence analysis}

For the constructions of the first (Lb-1), second (Lb-2) and third (Lb-3) libraries, we used the accessions BGP 86, BGP 80 and BGP 8, respectively. The libraries were constructed as described in [19]. DNA samples were digested using $A f a \mathrm{I}$ endonuclease (Invitrogen, Carlsbad, California, USA) and were then ligated to the double-stranded AfaI adapters (5'-CTCTTGCTTACGCGTGGACTA-3') and (5'-TAGTCCACGCGTAAGCAAGAGCACA-3'). An enrichment was performed using hybridization-based capture with (GT) 8 and (CT) 8 biotinylated probes and streptavidin-coated magnetic beads (Streptavidin Magnesphere Paramagnetic Particles, Promega, Madison, Wisconsin, USA). Selected DNA fragments were amplified by PCR and then cloned into the pGEM-T Easy vector (Promega, Madison, Wisconsin, USA). Competent Escherichia coli XL1-Blue cells (Stratagene, Agilent Technologies, Santa Clara, California, USA) were transformed with recombinant plasmids via the electroporation method and were then cultivated on agar medium containing ampicillin $(100 \mathrm{mg} / \mathrm{ml}), \mathrm{X}$-galactosidase $2 \%$ $(100 \mu \mathrm{g} / \mathrm{ml})$ and IPTG $(100 \mathrm{mM})$. Positive clones were randomly selected using white/blue screening and were sequenced on an automated ABI 3500xL Genetic Analyzer (Applied Biosystems, Foster City, California, USA) using T7 and SP6 primers and a BigDye Terminator version 3.1 Cycle Sequencing Kit (Applied Biosystems).

All obtained sequences were analyzed to identify microsatellite-enriched regions with the Simple Sequence Repeat Identification Tool (SSRIT) [20], and oligonucleotides complementary to genomic sequences flanking the microsatellite region were designed using Primer3Plus [21] with the following criteria: preferable primer size between 18 and $22 \mathrm{bp}$; melting temperature (Tm) between 50 and $60{ }^{\circ} \mathrm{C}$; amplified product length between 100 and $300 \mathrm{bp}$; and GC content between 40 and $60 \%$. Following these criteria, 56 primer pairs were designed and synthesized for analysis. 
Table 1 Genotypes of Paspalum spp. of the Plicatula group used for the characterization and transferability analyses of the new microsatellite markers

\begin{tabular}{|c|c|c|c|c|c|c|}
\hline AN & $\begin{array}{l}\text { Local code } \\
\text { (BGP) }\end{array}$ & Species & Collector code & Latitude & Longitude & Collection site \\
\hline 1 & 8 & Paspalum plicatulum & V D Fi [7441] & -27.950000 & -50.450000 & Capão Alto, Santa Catarina, Brazil \\
\hline 2 & 67 & Paspalum plicatulum & V BoPrSe [4258] & -30.116667 & -51.966667 & Butiá, Rio Grande do Sul, Brazil \\
\hline 3 & 39 & Paspalum rhodopedum & V MrFr [9851] & -28.250000 & -51.866667 & Caseiros, Rio Grande do Sul, Brazil \\
\hline 4 & 90 & Paspalum plicatulum & EEA [149] & -30.100000 & -51.316667 & Guaíba, Rio Grande do Sul, Brazil \\
\hline 5 & 89 & Paspalum plicatulum & EEA [148] & -30.100000 & -51.316667 & Guaíba, Rio Grande do Sul, Brazil \\
\hline 6 & 88 & Paspalum plicatulum & EEA [147] & -30.100000 & -51.316667 & Guaíba, Rio Grande do Sul, Brazil \\
\hline 7 & 271 & Paspalum lenticulare & [14535] & -20.679722 & -55.296111 & $\begin{array}{l}\text { Dois Irmãos do Buriti, Mato Grosso do } \\
\text { Sul, Brazil }\end{array}$ \\
\hline 8 & 220 & $\begin{array}{l}\text { Paspalum compressifo- } \\
\text { lium }\end{array}$ & V [14196] & -28.833333 & -51.566667 & Vila Flores, Rio Grande do Sul, Brazil \\
\hline 9 & 71 & Paspalum plicatulum & V BoPrSe [4337] & -30.400000 & -54.316667 & São Gabriel, Rio Grande do Sul, Brazil \\
\hline 10 & 226 & Paspalum plicatulum & $\begin{array}{l}\text { V, Chies \& Palmieri } \\
{[14206]}\end{array}$ & -28.283333 & -52.450000 & Passo Fundo, Rio Grande do Sul, Brazil \\
\hline 11 & 109 & Paspalum plicatulum & V BolrSv [9981] & -32.116667 & -52.350000 & Rio Grande, Rio Grande do Sul, Brazil \\
\hline 12 & 172 & Paspalum plicatulum & V Q FdSv [11893] & -22.933889 & -55.635278 & Aral Moreira, Mato Grosso do Sul, Brazil \\
\hline 13 & 83 & Paspalum plicatulum & V BoPr01 [4741] & -29.000000 & -53.666667 & Tupanciretã, Rio Grande do Sul, Brazil \\
\hline 14 & 73 & Paspalum plicatulum & V BoPrSe [4347] & -30.250000 & -54.533333 & São Gabriel, Rio Grande do Sul, Brazil \\
\hline 15 & 232 & Paspalum plicatulum & $\begin{array}{l}\text { V, Chies \& Palmieri } \\
\text { [14229] }\end{array}$ & -28.450000 & -55.133333 & $\begin{array}{l}\text { São Luiz Gonzaga, Rio Grande do Sul, } \\
\text { Brazil }\end{array}$ \\
\hline 16 & 177 & Paspalum plicatulum & V GoMiSv [11082] & -25.450000 & -49.383333 & Campo Largo, Paraná, Brazil \\
\hline 17 & 179 & $\begin{array}{l}\text { Paspalum compressifo- } \\
\text { lium }\end{array}$ & V GoMiSv [11101] & -25.450000 & -49.633333 & Campo Largo, Paraná, Brazil \\
\hline 18 & 180 & Paspalum plicatulum & V GoMiSv [11102] & -25.450000 & -49.633333 & Balsa Nova, Paraná, Brazil \\
\hline 19 & 181 & Paspalum plicatulum & V GoMiSv [11141] & -25.316667 & -49.050000 & Campina Grande do Sul, Paraná, Brazil \\
\hline 20 & 182 & Paspalum plicatulum & V GoMiSv [11142] & -25.316667 & -49.050000 & Quatro Barras, Paraná, Brazil \\
\hline 21 & 261 & Paspalum plicatulum & [14496] & -18.766667 & -51.300000 & Itarumã, Goiás, Brazil \\
\hline 22 & 279 & Paspalum atratum & V [14554] & -20.483611 & -55.806944 & Anastácio, Mato Grosso do Sul, Brazil \\
\hline 23 & 243 & Paspalum plicatulum & Rc [1333] & -7.350000 & -46.600000 & Riachão, Paraíba, Brazil \\
\hline 24 & 265 & Paspalum plicatulum & $V$ [14503] & -19.566667 & -51.233333 & Paranaíba, Mato Grosso do Sul, Brazil \\
\hline 25 & 198 & Paspalum plicatulum & V GoSv [11450] & -26.516667 & -51.916667 & Palmas, Tocantins, Brazil \\
\hline 26 & 197 & Paspalum plicatulum & VGoSv 11447 & -26.516667 & -51.916667 & Palmas, Tocantins, Brazil \\
\hline 27 & 301 & Paspalum plicatulum & VPoRcMmSv 14630 & -20.566667 & -54.683333 & Campo Grande, Mato Grosso do Sul, Brazil \\
\hline 28 & 164 & Paspalum plicatulum & VQFdSv 11826 & -22.150000 & -54.833333 & Itaporã, Mato Grosso do Sul, Brazil \\
\hline 29 & 159 & Paspalum guenoarum & VQFdSV 12739 & -20.633333 & -51.100000 & Pereira Barreto, São Paulo, Brazil \\
\hline 30 & 87 & Paspalum plicatulum & EEA 81 & -30.400000 & -54.316667 & São Gabriel, Rio Grande do Sul, Brazil \\
\hline 31 & 80 & Paspalum plicatulum & VBoPrOl 4644 & -28.983333 & -55.300000 & São Borja, Rio Grande do Sul, Brazil \\
\hline 32 & 137 & Paspalum plicatulum & VGoMi 10728 & -28.833333 & -52.433333 & Soledade, Rio Grande do Sul, Brazil \\
\hline 33 & 259 & Paspalum lenticulare & V 14487 & -17.416667 & -50.400000 & Acreúna, Goiás, Brazil \\
\hline 34 & 165 & Paspalum lenticulare & VQFdSv 11827 & -22.150000 & -54.833333 & Dourados, Mato Grosso do Sul, Brazil \\
\hline 35 & 284 & Paspalum guenoarum & VRcMmSv 14568 & -22.250000 & -54.966667 & Dourados, Mato Grosso do Sul, Brazil \\
\hline 36 & 153 & $\begin{array}{l}\text { Paspalum compressifo- } \\
\text { lium }\end{array}$ & DGoMi 480 & -27.383333 & -51.133333 & Campos Novos, Santa Catarina, Brazil \\
\hline 37 & 296 & Paspalum rhodopedum & VRcMmSv 14616 & -22.400000 & -54.783333 & Dourados, Mato Grosso do Sul, Brazil \\
\hline 38 & 151 & Paspalum rhodopedum & DGoMi 311 & -27.671667 & -51.460556 & Barracão, Rio Grande do Sul, Brazil \\
\hline 39 & 249 & $\begin{array}{l}\text { Paspalum compressifo- } \\
\text { lium }\end{array}$ & VTsOlTf14431 & -30.100000 & -51.783333 & Arroio dos Ratos, Rio Grande do Sul, Brazil \\
\hline 40 & 407 & Paspalum lepton & - & - & - & - \\
\hline 41 & 374 & Paspalum guenoarum & - & - & - & - \\
\hline 42 & 212 & Paspalum guenoarum & - & -30.200000 & -56.216667 & Quaraí, Rio Grande do Sul, Brazil \\
\hline
\end{tabular}


Table 1 continued

\begin{tabular}{lllllll}
\hline AN & $\begin{array}{l}\text { Local code } \\
\text { (BGP) }\end{array}$ & Species & Collector code & Latitude & Longitude & Collection site \\
\hline 43 & 280 & Paspalum atratum & VRcMmSv 14557 & -20.483611 & -55.806944 & Anastácio, Mato Grosso do Sul, Brazil \\
44 & 35 & Paspalum guenoarum & VMrFrLw 9813 & -28.916667 & -55.600000 & São Borja, Rio Grande do Sul, Brazil \\
45 & 15 & Paspalum atratum & VPoPrJAr 8687 & -20.300000 & -56.416667 & Miranda, Mato Grosso do Sul, Brazil \\
46 & 283 & Paspalum rojasii & VRcMmSv 14567 & -22.250000 & -54.966667 & Dourados, Mato Grosso do Sul, Brazil \\
47 & 264 & Paspalum guenoarum & V 14502 & -19.566667 & -51.233333 & Paranaíba, Mato Grosso do Sul, Brazil \\
48 & 300 & Paspalum rojasii & VPoRcMmSv 14628 & -20.500000 & -54.733333 & Campo Grande, Mato Grosso do Sul, Brazil \\
\hline
\end{tabular}

Collectors: Ar = M.R.Araújo, Bo = S.C.Boechat, $\mathrm{D}=$ M.Dall'Agnol, Dp = Dario Palmieri, Fd = M.S.França Dantas, Fi $=$ R.G.Fischer, Fr $=$ J.M.O.Freitas, Go $=$ K.E.Gomes, $\mathrm{Ir}=$ B.E.Irgang, $\mathrm{J}=$ L.Jank, $\mathrm{Lw}=$ H.M.Longhi-Wagner, $\mathrm{Mi}=$ S.T.S.Miotto, $\mathrm{Mm}=$ M.D.Moraes, $\mathrm{Mr}=$ C.O.C.Moraes, OI = M.L.A.A.Oliveira, Po $=$ A.Pott, Pr $=$ A.I.C.Pereira, $\mathrm{Q}=$ Camilo Luís Quarín, Rc = Regina Célia de Oliveira, Se = B.A.Severo, Sv = Glocimar Pereira da Silva, Tf $=$ T.F.Ferreira, Ts $=$ T.Souza-Chies, V $=$ José Francisco Montenegro Valls. Abbreviation: $\mathrm{EEA}=$ Agronomic Experimental Station of the UFRGS

\section{Fragment amplification and statistical analysis}

Polymerase chain reactions (PCRs) were performed in a $15-\mu \mathrm{l}$ final volume containing $30 \mathrm{ng}$ of template DNA, $1 \times$ PCR buffer $(20 \mathrm{mM}$ Tris $\mathrm{HCl}[\mathrm{pH} 8.4]$ and $50 \mathrm{mM}$ $\mathrm{KCl}), 1.5 \mathrm{mM} \mathrm{MgCl} 2,0.2 \mathrm{mM}$ of each dNTP, $10 \mathrm{mg} / \mathrm{ml}$ bovine serum albumin (BSA), $0.5 \mathrm{mM}$ of each primer, and $1 \mathrm{U}$ of Taq DNA polymerase (Invitrogen, Carlsbad, California, USA). The PCR program used for all loci amplifications was as follows: $2 \mathrm{~min} 30 \mathrm{~s}$ of initial denaturation at $94{ }^{\circ} \mathrm{C}$ followed by 35 cycles of denaturation at $94{ }^{\circ} \mathrm{C}$ for $1 \mathrm{~min}$, the specific annealing temperature of each primer pair (Table 2), extension at $72{ }^{\circ} \mathrm{C}$ for $1 \mathrm{~min}$, and a final extension at $72{ }^{\circ} \mathrm{C}$ for $8 \mathrm{~min}$. Amplified products were preliminarily checked on $3 \%$ agarose gels prior to genotyping using silver-stained $6 \%$ denaturing polyacrylamide gels [22], and product sizes were determined using a 10-bp DNA ladder (Invitrogen, Carlsbad, California, USA). Microsatellites were treated as dominant markers due to the polyploid nature of the genotypes. Accordingly, the data were scored based on the presence (1) or absence (0) of a band for each of the Paspalum genotypes. In dominant locus patterns, estimates of allelic frequencies are not possible; therefore, observed heterozygosity was not estimated. As such, polymorphism information content (PIC) was used to evaluate and characterize microsatellite loci using the formula

$$
\text { PIC }=1-\sum_{i=1}^{n} p_{i}^{2}-\sum_{i=1}^{n} \sum_{j=i+1}^{n} 2 p_{i}^{2} p_{j}^{2},
$$

where $\mathrm{n}$ is the number of bands of the marker among the set of samples used for characterizing the microsatellite polymorphism and pi and pj are the frequencies of bands $i$ and $j$ [23]. Discriminatory power (DP) [24] values were calculated to compare the efficiencies of microsatellite markers in varietal identification.
Two approaches were used to evaluate the population structure and grouping of the accessions studied: STRUCTURE and Discriminant Analysis of Principal Components (DAPC).

The model-based Bayesian analysis implemented in the software package STRUCTURE [25] was used to determine the approximate number of genetic clusters (K) within the full data set and to assign individuals to the most appropriate cluster. All simulations were performed using the admixture model, with 500,000 replicates for burn-in and 1000,000 replicates for Markov Chain Monte Carlo (MCMC) processes in ten independent runs. The numbers of clusters $(\mathrm{K})$ tested ranged from 1 to 15 . The optimal number of clusters was determined by calculating the $\ln (\mathrm{K})$ and $\Delta \mathrm{K}$ values, as previously described by [26] and as implemented in STRUCTURE HARVESTER [27]. A consensus STRUCTURE plot was obtained from the admixture repeats using the greedy algorithm in CLUMPP [28], and final plots were produced using STRUCTURE PLOT [29].

A DAPC analysis as implemented in the $\mathrm{R}$ package adegenet was also performed, which uses a nonparametric approach, free from Hardy-Weinberg constraints, as described in [30]. Two approaches were conducted: (1) the first DAPC analysis was performed, providing the information of eight groups according to biological information (eight species); and (2) a priori definition of clusters to study population structure was required; therefore, the number of clusters was assessed using the function find.clusters, which runs successive K-means clustering with increasing numbers of clusters (k). We assumed 15 as the maximum number of clusters. The optimal number of clusters was estimated using the Bayesian information criterion (BIC), which reaches a minimum when the best-supported assignment of individuals to the appropriate number of clusters is approached. Both DAPC results are presented as multidimensional scaling plots. 


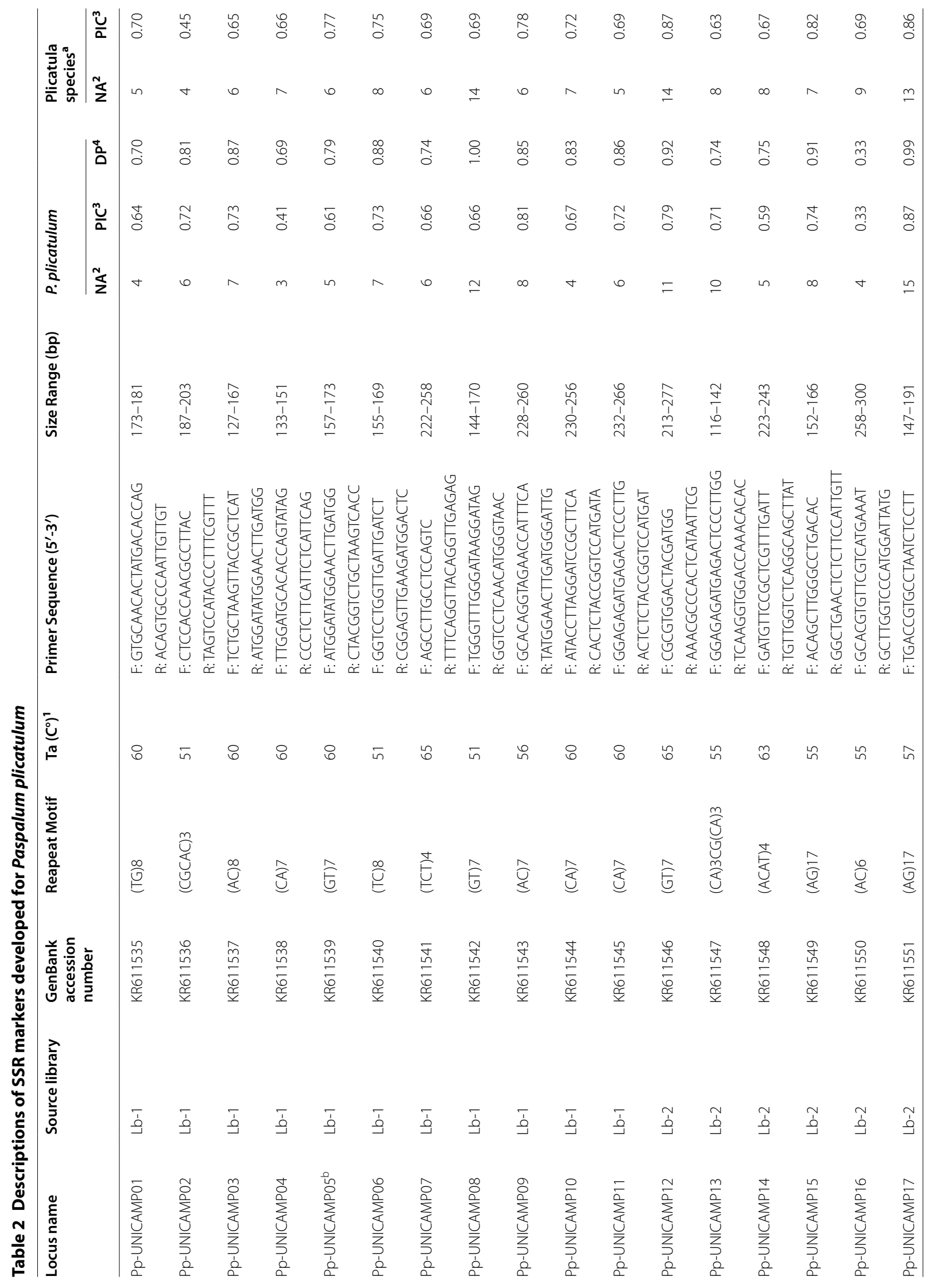




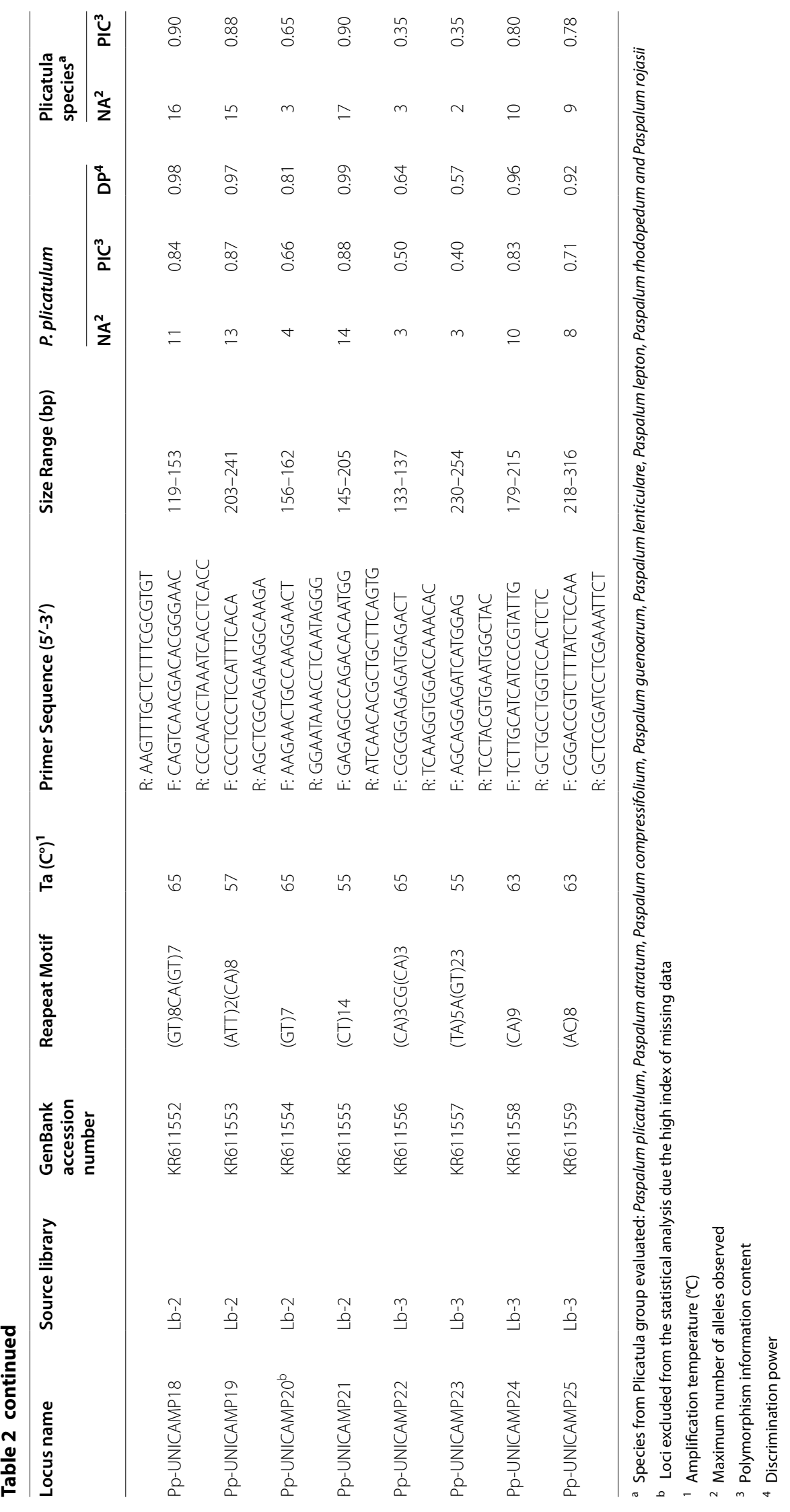




\section{Results and discussion}

For Lb-1, we selected and sequenced 144 positive clones, which yielded 109 contigs containing 33 simple sequence repeat (SSR) sequences. From these sequences, 24 primer pairs were designed and tested. Six were eliminated from the analysis because they did not amplify fragments under the various conditions tested, two had amplification artifacts that made genotyping impossible and five were monomorphic. Thus, 11 polymorphic loci were obtained from Lb-1. In addition to this library, more two genomic libraries were constructed, Lb-2 and Lb-3, with the aim of increasing the number of loci and providing greater robustness in the analysis. A total of 192 positive clones were selected and sequenced, but due to the time required for amplification tests of primer pairs and genotyping, added to the costs involved, we selected only the best sequences of each library to design primer pairs according to the desired parameters. Thirty-two additional primer pairs were designed: 23 from Lb- 2 and 9 from Lb-3. From these, four primer pairs were eliminated because they did not amplify fragments, nine had amplification artifacts and five were monomorphic. Thus, more 14 polymorphic loci were obtained (ten from Lb-2 and four from Lb-3).

Twenty-five markers were polymorphic and successfully transferred to the other Paspalum species tested. The description of the number of bands per locus and the PIC and DP values for both P. plicatulum accessions and other Paspalum species are shown in Table 2. Two loci were excluded from statistical analyses because they presented high indices of missing data (Pp-UNICAMP05 and Pp-UNICAMP20). Of the 23 loci analyzed, the number of bands per locus for P. plicatulum ranged from 3 to 15 , with an average of 7.74. Among the species of the Plicatula group, the number of bands ranged from 2 to 17, with an average of 8.65 bands per locus.

Private bands were observed for all species, with the exception of $P$. rojasii (Table 3 ). We use the term "private band" to describe bands that are observed in only one species (Fig. 1). Paspalum plicatulum had the highest number of these bands, with more than half of the analyzed loci (52\%) showing at least one band unique to this species. Paspalum atratum showed the second highest value of private bands, which were observed in $32 \%$ of loci. The number of private bands observed, can decrease as more individuals of other species are analyzed. However, this result was interesting since only three individuals of $P$. atratum were analyzed. Private bands in a population are a simple measure of genetic distinctiveness. For the purposes of conservation and management, private bands are crucial for early detection and intervention in populations at early stages of introgression and for prioritizing conservation and recovery programs [31].
Furthermore, a large, reliable, well-chosen set of speciesdiagnostic markers can be used to help identify species, which is extremely valuable in the management of germplasm banks.

PIC values obtained for the 23 loci analyzed ranged from 0.33 to 0.88 , with an average of 0.69 for $P$. plicatu$l u m$, and from 0.35 to 0.90 , with an average of 0.71 across the species from the Plicatula group. According to the classification proposed by Botstein [32], twenty of our loci were classified as highly informative ( $\mathrm{PIC} \geq 0.5$ ). DP values ranged from 0.33 to 1.00 , with a mean of 0.82 observed for P. plicatulum. When the PIC and DP of each locus were analyzed together, five loci presented the highest values in both indexes: Pp-UNICAMP21, PpUNICAMP17, Pp-UNICAMP18, Pp-UNICAMP19 and Pp-UNICAMP24, in order of higher informativeness.

Microsatellite markers were satisfactorily cross-amplified for Paspalum species within the Plicatula group. Paspalum atratum presented the highest detected transferability (89.86\%); this species is closely related to P. plicatulum. Paspalum atratum is highly polymorphic and is related to the "common" biotype of P. plicatulum [16]. Killeen [33] relates $P$. plicatulum var. robustum Hack. in synonymy to $P$. atratum. The transferability rates of the loci were also high for P. compressifolium (85.87\%), P. lenticulare (82.61\%) and P. guenoarum (78.26\%). The success of transferability between species, as observed for other Paspalum species [34, 35] and between correlated grass species [36, 37], allows the reduction of time and costs in the development of new markers. Only the Pp-UNICAMP23 locus could not be amplified in $P$. rojasii. PpUNICAMP01 did not amplify in P. rhodopedum, $P$. rojasii or P. lepton. A total of eight loci did not amplify in P. lepton, which may have occurred due to the use of only one accession of this species in the study. The results of the cross-amplification tests are shown in Table 4.

The Bayesian analyses of population structure were input into STRUCTURE HARVESTER for computation of mean $\mathrm{LnP}(\mathrm{K})$ and $\Delta \mathrm{K}$, which peaked at $\mathrm{K}=3$, suggesting that three genetic clusters were sufficient to interpret the Paspalum germplasm data (Fig. 2); the results are also presented for $K=6$, which was the second best $K$ (Additional file 1). From the eight species from Plicatula group analyzed, 16 accessions were assigned to cluster 1 (red), 20 were assigned to cluster 2 (blue) and ten were assigned to cluster 3 (green) (Fig. 3) (Additional file 2). Two accessions of $P$. plicatulum did not sort to defined clusters. There was a tendency of $P$. plicatulum individuals to cluster with each other, but mainly in clusters 1 and 3 . The remaining species were mostly classified into a mixed subgroup (cluster 2). However, no clear pattern for the assignment of individuals based on species was observed. The results of this analysis can be extremely 
Table 3 Numbers of private bands of the 25 SSR markers in Paspalum plicatulum and in the seven other Paspalum species from the Plicatula group

\begin{tabular}{|c|c|c|c|c|c|c|c|c|}
\hline Locus name & P.plicatulum & P. atratum & P. compressifolium & P. guenoarum & P. lenticulare & P. lepton & P. rhodopedum & P. rojasii \\
\hline Pp-UNICAMP01 & & & 1 & & & & & \\
\hline Pp-UNICAMP02 & 1 & & & & & & & \\
\hline \multicolumn{9}{|l|}{ Pp-UNICAMP03 } \\
\hline Pp-UNICAMP04 & & 1 & 2 & & & & & \\
\hline Pp-UNICAMP05 & 2 & 1 & & & & 2 & & \\
\hline Pp-UNICAMP06 & & & & 1 & & & & \\
\hline \multicolumn{9}{|l|}{ Pp-UNICAMP07 } \\
\hline Pp-UNICAMP08 & & 1 & & & & & & \\
\hline Pp-UNICAMP09 & 1 & & & & & & & \\
\hline Pp-UNICAMP10 & & 1 & & & & & 1 & \\
\hline Pp-UNICAMP11 & 1 & & & & & & & \\
\hline Pp-UNICAMP12 & 3 & & & 2 & & & & \\
\hline Pp-UNICAMP13 & 2 & & & & & & & \\
\hline Pp-UNICAMP14 & & 1 & & & 1 & & & \\
\hline Pp-UNICAMP15 & 1 & & & & & & & \\
\hline Pp-UNICAMP16 & & 1 & & & & & 1 & \\
\hline Pp-UNICAMP17 & 5 & & & 1 & 1 & & & \\
\hline Pp-UNICAMP18 & & & & 1 & 3 & & & \\
\hline Pp-UNICAMP19 & 1 & & & 1 & & & & \\
\hline \multicolumn{9}{|l|}{ Pp-UNICAMP20 } \\
\hline Pp-UNICAMP21 & 2 & 2 & & & & & 2 & \\
\hline \multicolumn{9}{|l|}{ Pp-UNICAMP22 } \\
\hline Pp-UNICAMP23 & 1 & & & & & & & \\
\hline Pp-UNICAMP24 & 1 & 1 & & & & & & \\
\hline Pp-UNICAMP25 & 1 & & & & & & & \\
\hline $\begin{array}{l}\text { Number of loci with private } \\
\text { bands }\end{array}$ & 13 & 8 & 2 & 5 & 3 & 1 & 3 & 0 \\
\hline$\%$ of loci with private bands & 52 & 32 & 8 & 20 & 12 & 4 & 12 & 0 \\
\hline
\end{tabular}

useful in breeding programs to guide the choice of accessions to cross. Because the gene pool is shared between accessions of the same cluster, the success rates of crossing them may be higher.

Additionally, two DAPC analyses were performed, and the results are presented as multidimensional scaling plots in Figs. 4 and 5. For both, we retained the first 16 principal components of the PCA, which explained $65 \%$ of the variation. In the first approach, we used DAPC to investigate the genetic structure of the sampled individuals, using species information pre-established by taxonomic classification (Fig. 4). The data were divided into two clear clusters: the first cluster consisted only of $P$. atratum individuals, and the second cluster consisted of all individuals from the remaining seven Paspalum species. The genetic closeness of these species favors sharing alleles, which complicates delineation between the different taxa of the Plicatula group. This difficulty was also reported by Cidade et al. [17]. However, the separation of $P$. atratum genotypes into a distinct cluster could be related to the efficiency of amplification of the developed loci and the detection of a high number of unique bands. DAPC has been proposed as an alternative to Bayesian clustering [30] as the method does not assume a population genetic model and yields better visualization of the relative distances between groups. In the second approach, we assumed no prior information about groupings of the accessions evaluated. Therefore, we searched for the best-supported number of clusters using the $\mathrm{K}$-means algorithm. Inspection of BIC values (Additional file 3) revealed that two clusters were the most probable to explain the variance in these groups of accessions as the number of clusters should be $\geq 2$, as stated by the software. However, we selected three clusters to illustrate the true genetic clusters and consequently compared the results to the three clusters obtained with STRUCTURE (Fig. 5). The allocation of individuals to clusters from DAPC was similar to those achieved by STRUCTURE, 


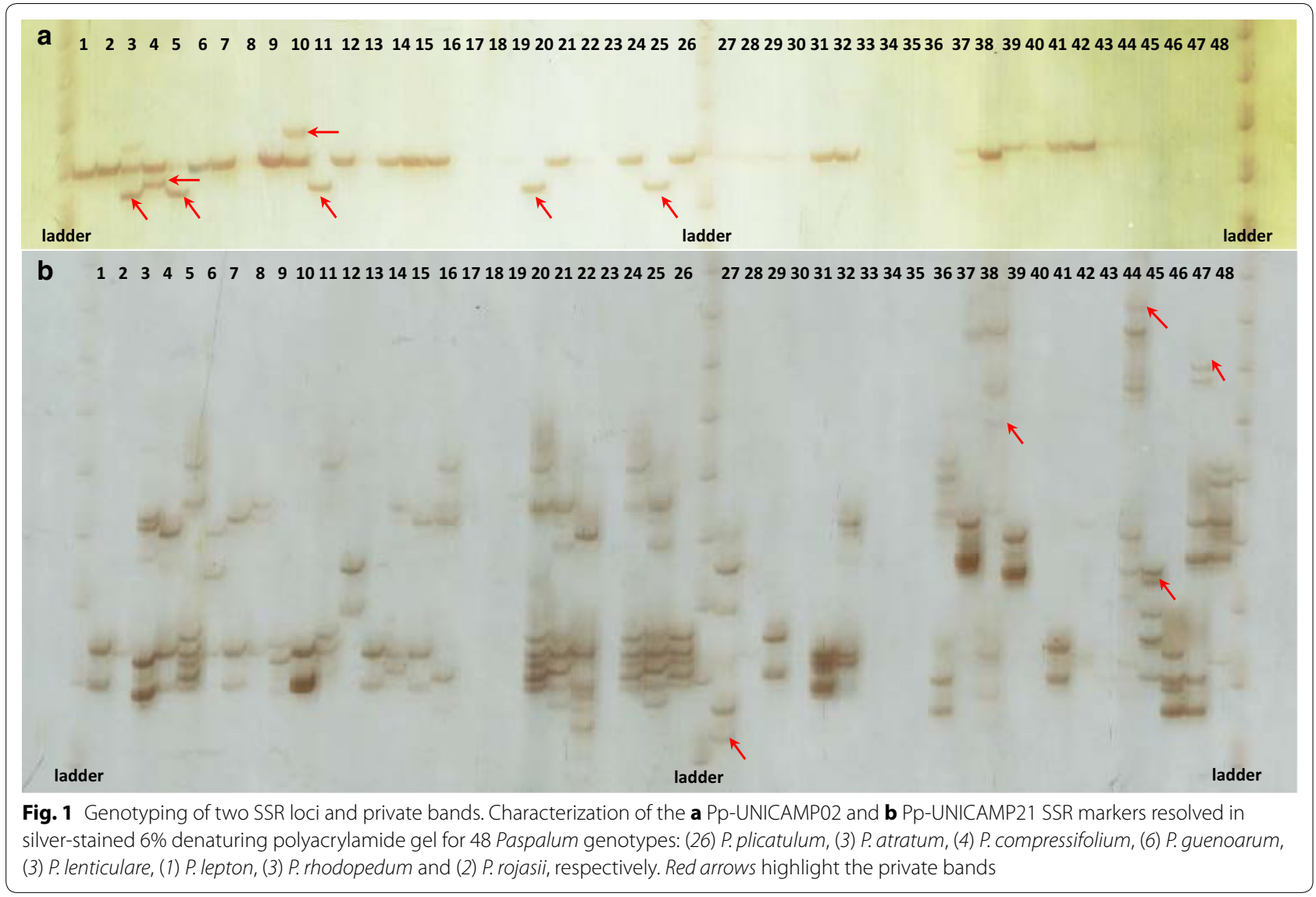

and both analyses showed the same pattern of clustering. Essentially, clusters 1 (red), 2 (blue) and 3 (green) of DAPC reflect the division of gene pools 1 (red), 2 (blue) and 3 (green) detected by STRUCTURE, respectively (Additional file 2).

In both analyses, there was no clear delimitation of taxa within our dataset, compared to that expected according to the number of species studied here. In general, Paspalum species of the Plicatula group do not present a clear boundary forming an intricate agamic complex [16]. During species identification, it is common to distinguish among related species using only a few morphological descriptors. In Fig. 3, the unique accession of $P$. lepton was located in cluster 1 , where there is a higher concentration of $P$. plicatulum accessions. Paspalum lepton is associated with P. plicatulum based on general morphological aspects of both plant and spikelet, although the latter species does not possess leptomorph rhizomes. Paspalum lepton is also associated with $P$. rhodopedum by the presence of long leptomorph rhizomes, however, the most typical accessions of $P$. lepton are characterized by the presence of small and gray plants [38]. In Fig. 3 , the accessions of $P$. rhodopedum appeared to be divided into two clusters. Distinguishing the studied species through taxonomic identification using only morphological characters has proven to be a difficult task. $P$. rhodopedum is strongly related to $P$. rojasii, and it is practically impossible to distinguish the two species without the presence of the base of the plant [16]. Zuloaga et al. [39] proposed the synonymization of these species, but $P$. rhodopedum has leptomorph rhizomes, and $P$. rojasii has pachymorph rhizomes. Zuloaga et al. [39] synonymized $P$. guenoarum and $P$. rojasii. These authors also synonymized $P$. rhodopedum to $P$. guenoarum var. rojasii, even though the first has long and characteristic leptomorph rhizomes [16], as an Israeli chandelier, and $P$. guenoarum does not have rhizomes. Figure 3 shows that accessions of $P$. rojasii grouped with $P$. guenoarum and P. rhodopedum. Paspalum atratum is morphologically similar to P. plicatulum and P. lenticulare [38]. One of the morphological characteristics that distinguish $P$. atratum from $P$. lenticulare is that the first has an unbranched stem and the other has a branched colm [16]. The presence of fungi from the genus Bipolaris is another morphological characteristic that can be observed in the field for both $P$. atratum and $P$. lenticulare. P. compressifolium is a species of glaucous leaves and extremely flat fanshaped sheaths and is also taxonomically associated with 
Table 4 Cross-amplification of the 25 SSR markers among the other Paspalum species evaluated

\begin{tabular}{|c|c|c|c|c|c|c|c|}
\hline Locus name & P. atratum & P. compressifolium & P. guenoarum & P. lenticulare & P. lepton & P. rhodopedum & P. rojasii \\
\hline Pp-UNICAMP01 & 3_3 & 3_4 & $2 \_6$ & $3 \_3$ & 0_1 & $0 \_3$ & $0 \_2$ \\
\hline Pp-UNICAMP02 & $2 \_3$ & 4_4 & 5_6 & $3 \_3$ & 0_1 & $2 \_3$ & $1 \_2$ \\
\hline Pp-UNICAMP03 & $2 \_3$ & 3_4 & $5 \_6$ & $3 \_3$ & 0_1 & $2 \_3$ & $1 \_2$ \\
\hline Pp-UNICAMP04 & $3 \_3$ & 4_4 & 4_6 & 3_3 & $1 \_1$ & $2 \_3$ & $1 \_2$ \\
\hline Pp-UNICAMP05 & $2 \_3$ & 3_4 & $1 \_6$ & $0 \_3$ & 0_1 & $0 \_3$ & $0 \_2$ \\
\hline Pp-UNICAMP06 & 3_3 & 4_4 & $6 \_6$ & $3 \_3$ & $1 \_1$ & $2 \_3$ & $2 \_2$ \\
\hline Pp-UNICAMP07 & 3_3 & 4_4 & 5_6 & 3_3 & $1 \_1$ & 3_3 & $1 \_2$ \\
\hline Pp-UNICAMP08 & $3 \_3$ & 4_4 & $6 \_6$ & $3 \_3$ & $1 \_1$ & $2 \_3$ & $1 \_2$ \\
\hline Pp-UNICAMP09 & $2 \_3$ & $2 \_4$ & 3_6 & $2 \_3$ & 0_1 & $2 \_3$ & $1 \_2$ \\
\hline Pp-UNICAMP10 & $3 \_3$ & 4_4 & 5_6 & $3 \_3$ & $1 \_1$ & $3 \_3$ & $1 \_2$ \\
\hline Pp-UNICAMP11 & $3 \_3$ & 4_4 & 5_6 & 3_3 & $1 \_1$ & 3_3 & $1 \_2$ \\
\hline Pp-UNICAMP12 & $2 \_3$ & 4_4 & 5_6 & 3_3 & 0_1 & $1 \_3$ & $1 \_2$ \\
\hline Pp-UNICAMP13 & 3_3 & 4_4 & $5 \_6$ & 3_3 & $1 \_1$ & 3_3 & $2 \_2$ \\
\hline Pp-UNICAMP14 & 3_3 & 4_4 & 5_6 & 3_3 & $1 \_1$ & $1 \_3$ & $2 \_2$ \\
\hline Pp-UNICAMP15 & $2 \_3$ & 4_4 & 5_6 & $2 \_3$ & 0_1 & $2 \_3$ & $2 \_2$ \\
\hline Pp-UNICAMP16 & $2 \_3$ & 4_4 & 4_6 & $2 \_3$ & 0_1 & $2 \_3$ & $1 \_2$ \\
\hline Pp-UNICAMP17 & 3_3 & 4_4 & $6 \_6$ & $2 \_3$ & $1 \_1$ & $2 \_3$ & $2 \_2$ \\
\hline Pp-UNICAMP18 & $2 \_3$ & $1 \_4$ & 5_6 & 3_3 & 0_1 & $3 \_3$ & $1 \_2$ \\
\hline Pp-UNICAMP19 & 3_3 & 4_4 & 4_6 & 3_3 & $1 \_1$ & 3_3 & $1 \_2$ \\
\hline Pp-UNICAMP20 & $3 \_3$ & 4_4 & $1 \_6$ & 3_3 & $1 \_1$ & $0 \_3$ & $0 \_2$ \\
\hline Pp-UNICAMP21 & 3_3 & 4_4 & $4 \_6$ & $2 \_3$ & $1 \_1$ & $2 \_3$ & $1 \_2$ \\
\hline Pp-UNICAMP22 & 3_3 & 4_4 & 3_6 & $1 \_3$ & $1 \_1$ & $1 \_3$ & $1 \_2$ \\
\hline Pp-UNICAMP23 & 3_3 & $1 \_4$ & $6 \_6$ & $1 \_3$ & $1 \_1$ & $1 \_3$ & $0 \_2$ \\
\hline Pp-UNICAMP24 & $3 \_3$ & 4_4 & 5_6 & $2 \_3$ & $1 \_1$ & $2 \_3$ & $2 \_2$ \\
\hline Pp-UNICAMP25 & $3 \_3$ & $1 \_4$ & $5 \_6$ & $1 \_3$ & $1 \_1$ & $1 \_3$ & $1 \_2$ \\
\hline Total & 67 & 86 & 110 & 60 & 16 & 45 & 27 \\
\hline Amplification \% & 89.33 & 86.00 & 73.33 & 80.00 & 64.00 & 60.00 & 54.00 \\
\hline
\end{tabular}

${ }^{a}$ Number of successfully amplified genotypes_Number of tested genotypes

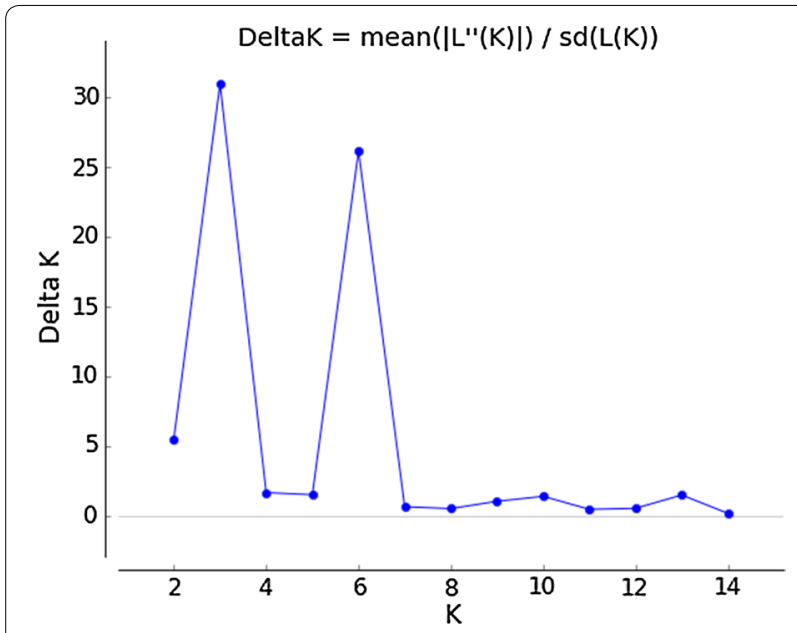

Fig. 2 STRUCTURE HARVESTER results. The approximate numbers of genetic clusters (K) within the full data set of 48 individuals based on results from the software package STRUCTURE. The $\triangle K$ [25] values are shown for each value of $\mathrm{K}$, from one to fifteen. Results are derived from ten independent simulations for each value of $K$. The results show the best support for $\mathrm{K}=3$
$P$. plicatulum. The accessions of $P$. compressifolium analyzed here showed a different grouping pattern compared to the other species considered in this study. Although the accessions were scattered among themselves and in different clusters, they were grouped with $P$. plicatulum (Fig. 3). However, P. plicatulum has wide morphological variability, is poorly understood and there is no consensus in the interpretation of the type specimen. The difficulty in defining this taxon and even the entire Plicatula group was highlighted by Killeen [33].

This result was expected because in a previous study [17], microsatellite markers (SSRs) developed for $P$. notatum and $P$. atratum were used in different Paspalum species, which allowed the authors to distinguish many different taxa, except for species belonging to the Plicatula group. Although high genetic variability within its species was observed, there was no clear distinction between different species in this botanical group. Furthermore, it is commonly known that the Plicatula group presents natural variation in morphological types [40], 


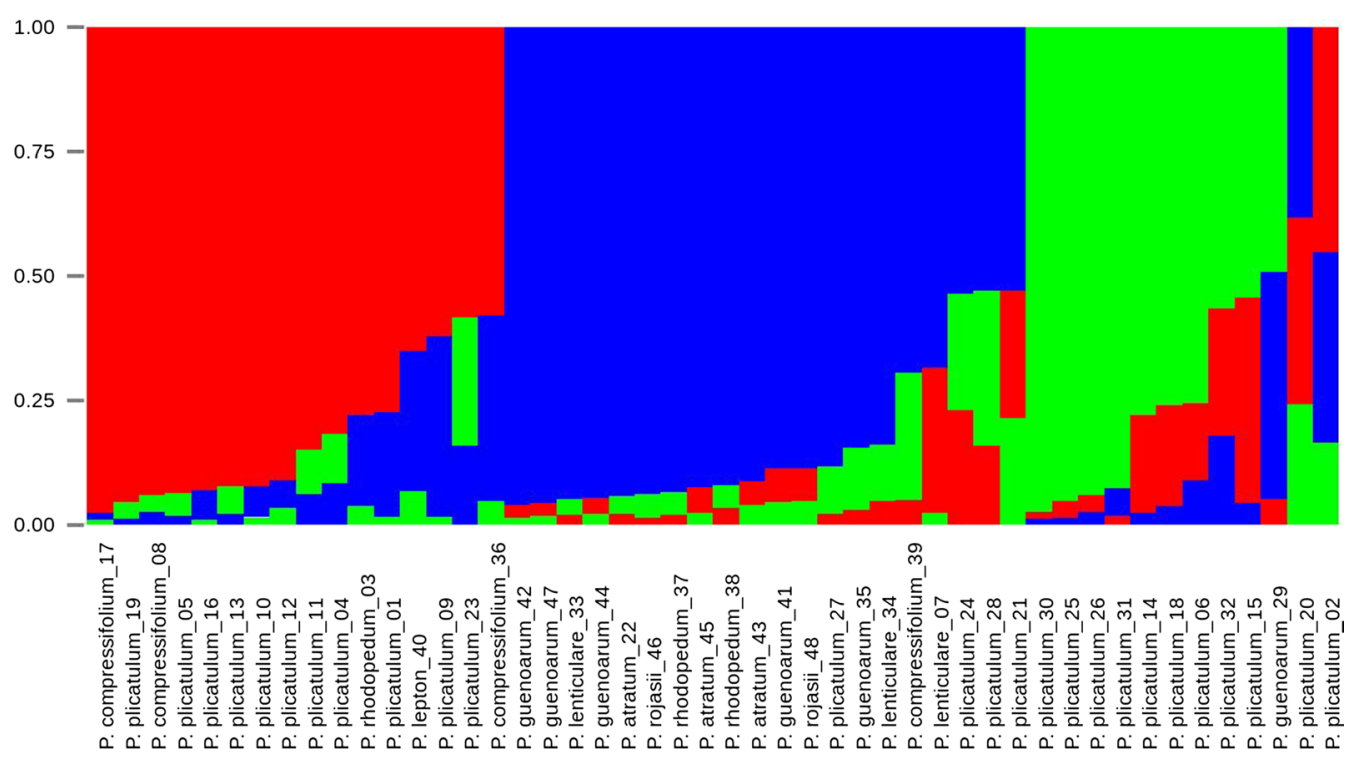

Fig. 3 Bar graph of the estimated membership coefficient, $Q$, for each of the 48 individuals. The most likely value of K inferred by STRUCTURE was three. Each genotype is represented by a vertical bar, and the colored segments represent the proportion of Q in each of the three clusters (red, blue and green). The data are an average of ten independent runs

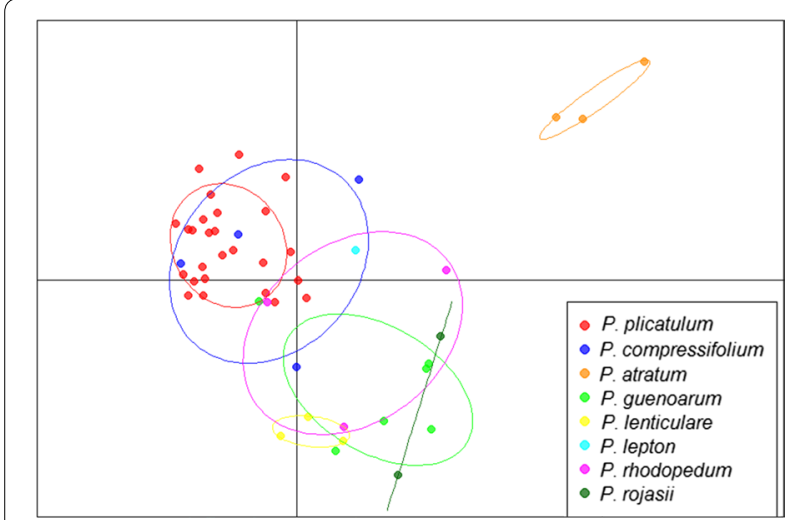

Fig. 4 Scatterplots of DAPC using eight species groupings. Dots represent individuals, and the species are represented with different colors and inertia ellipses: P. plicatulum, P. compressifolium, P. atratum, P. guenoarum, P. lenticulare, P. lepton, P. rhodopedum and P. rojasii. DAPC analysis identified two clusters within the data: one large cluster with all individuals from seven Paspalum species analyzed and another cluster consisting of Paspalum atratum individuals

coupled with hybridization throughout its evolution and high genetic variability within its species [17], making it a highly complex group with difficult taxonomic interpretation $[17,33]$. However, a more detailed and accurate analysis of the $P$. notatum accessions was undertaken, species from which molecular markers were developed and where species varieties could be separated (var. saurae and var. notatum) with the aid of private bands. Therefore, we believe that the absence of delimitation

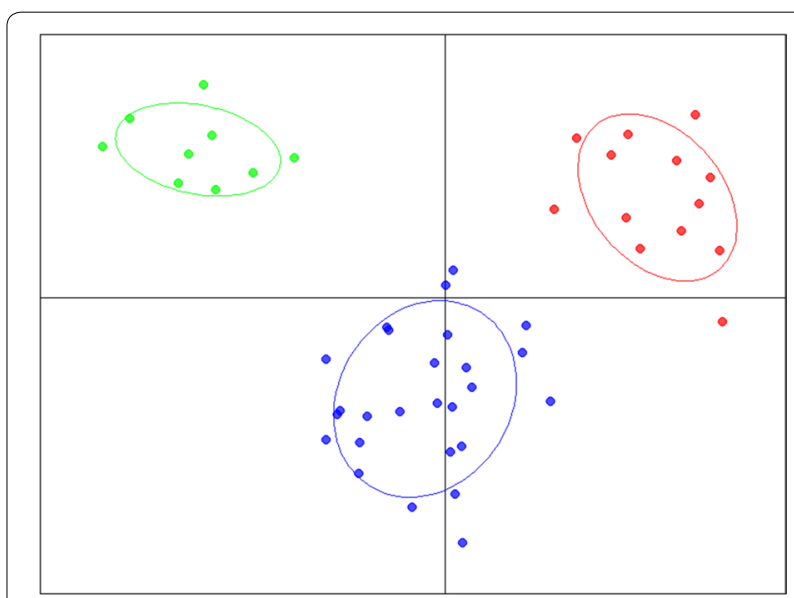

Fig. 5 DAPC scatterplots based on the K-means algorithm to determine the proper number of clusters. Dots represent individuals, and the clusters are represented with different colors and inertia ellipses. The individuals from different Paspalum species were allocated in three clusters: 1 (red), 2 (blue) and 3 (green)

between the taxa observed in our study may be related to the low number of genotypes of different species used in the analysis as the initial objective was only to test the transferability of loci.

The private bands identified in our study for seven different species from the Plicatula group present potential applications for species identification of samples and/ or new collections, what is mandatory for conservation, cytogenetics, breeding and other uses for Paspalum. 
However, these bands need further validation with larger numbers of genotypes from each species to be brought into practical use.

The microsatellites developed here are the first SSR markers developed for P. plicatulum and are highly transferrable to other species of the Plicatula group. These markers showed high polymorphism and were efficient in detecting genetic variations in the different species. These markers can be employed in future investigations of breeding programs, mating systems and kinship studies.

\section{Additional files}

Additional file 1. Bar graph of the estimated membership coefficients (Q) by STRUCTURE software for $\mathrm{K}=6$ for each of the 48 Paspalum genotypes evaluated.

Additional file 2. Allocation of Paspalum individuals based on the groups formed in the analysis of the STRUCTURE and DAPC. Groups 1 (red), 2 (blue) and 3 (green) for both analyses.

Additional file 3. Bayesian information criterion (BIC) for different numbers of clusters. The accepted true number of clusters was three.

\begin{abstract}
Abbreviations
AN: annotation number; BGP: codes of the accessions from EMBRAPA; BIC: Bayesian information criterion; bp: base pairs; BSA: bovine serum albumin; CAPES: coordination of improvement of higher education personnel; CTAB: cetyltrimethyl ammonium bromide; DAPC: discriminant analysis of principal components; DNA: deoxyribonucleic acid; DP: discrimination power; EMBRAPA: Brazilian Agricultural Research Corporation; K: number of clusters; Lb-1: library construction from BGP 86; Lb-2: library construction from BGP 80; Lb-3: library construction from BGP 8; MCMC: Markov Chain Monte Carlo; NA: number of alleles; PCR: polymerase chain reaction; PCA: principal components analysis; PIC: polymorphism information content; Q: association coefficient determined using STRUCTURE analysis; SSR: simple sequence repeat; SSRIT: simple sequence repeat identification tool; $\mathrm{Ta}\left({ }^{\circ} \mathrm{C}\right)$ : annealing temperature.
\end{abstract}

\section{Authors' contributions}

FAO and FWC developed microsatellite-enriched libraries, and FAO sequenced all libraries, performed computational searches for microsatellite identification, designed flanking primers, validated the microsatellite markers, performed the statistical analysis and drafted the manuscript. APF participated in the germplasm selection analysis and helped draft the manuscript. BBZV participated in the design and implementation of the study and statistical analysis and helped draft the manuscript. APS conceived of and supervised the study and helped draft the manuscript. All authors read and approved the final manuscript.

\section{Author details}

${ }^{1}$ Center for Molecular Biology and Genetic Engineering (CBMEG), University of Campinas (UNICAMP), Cidade Universitária Zeferino Vaz, CP 6010, Campinas, SP CEP 13083-970, Brazil. ${ }^{2}$ EMBRAPA Southeast Livestock, Brazilian Agricultural Research Corporation, CP 339, São Carlos, SP CEP 13560-970, Brazil. ${ }^{3}$ Plant Biology Department, Biology Institute, University of Campinas (UNICAMP), Cidade Universitária Zeferino Vaz, CP 6109, Campinas, SP CEP 13083-970, Brazil.

\section{Acknowledgements}

The authors thank João Paulo Gomes Viana for assisting with DAPC analysis. We are grateful to Fundação de Amparo à Pesquisa do Estado de São Paulo (FAPESP) for financial support (2005/51010-0 and 2008/52197-4) and a graduate fellowship (2006/61242-8; 2013/14903-2) awarded to FWC and FAO. We also thank the Coordenação de Aperfeiçoamento de Pessoal de Nível Superior (CAPES-EMBRAPA Fellowship Program) for graduate fellowships to FAO and to CAPES (Computational Biology Program - 051/2013) for grants, to the Brazilian
National Council for Scientific and Technological Development (CNPq) for a research fellowship and grants (307430/2007-3) awarded to APS.

\section{Competing interests}

The authors declare that they have no competing interests.

\section{Availability of data and materials}

The datasets supporting the results of this article are included in the article.

Received: 3 April 2016 Accepted: 1 December 2016

Published online: 13 December 2016

\section{References}

1. Zuloaga FO, Morrone O. Revisión de las especies de Paspalum para América del Sur Austral (Argentina, Bolivia, sur del Brasil, Chile, Paraguay y Uruguay). Monogr Syst Bot Mo Bot Gard. 2005;102:1-297.

2. Scataglini MA, Zuloaga FO, Giussani LM, Denham SS, Morrone O. Phylogeny of new world Paspalum (Poaceae, Panicoideae, Paspaleae) based on plastid and nuclear markers. Plant Syst Evol. 2014. doi:10.1007/ s00606-013-0944-1.

3. Paspalum in Flora do Brasil 2020 em construção. Jardim Botânico do Rio de Janeiro. http://floradobrasil.jbrj.gov.br/reflora/floradobrasil/FB13432. Accessed 29 Mar 2016.

4. Quarín CL, Burson BL. Cytology of sexual and apomictic paspalum species. Cytologia. 1991;56:223-8.

5. Morrone O, Escobar A, Zuloaga FO. Chromosome studies in American Panicoideae (Poaceae). Ann Mo Bot Gard. 2006:93:647-57.

6. Hojsgaard D, Honfi Al, Rua G, Daviña J. Chromosome numbers and ploidy levels of Paspalum species from subtropical South America (Poaceae). Genet Resour Crop Evol. 2009;56:533-45.

7. Quarín CL. The nature of apomixis and its origin in Panicoid grasses. Apomixis Newslett. 1992;5:8-15.

8. Quarín CL, Espinoza F, Martínez EJ, Pessino SC, Bovo OA. A rise of ploidy level induces the expression of apomixis in paspalum notatum. Sex Plant Reprod. 2001;13:243-9.

9. Pozzobon MT, de Carvalho Machado AC, Vaio M, Valls JFM, de Souza Peñaloza AP, dos Santos SD, et al. Cytogenetic analyses in Paspalum L. Reveal new diploid species and accessions. Cienc Rural. 2008;38:1292-9.

10. Norrmann GA, Quarín CL, Burson BL. Cytogenetics and reproductive behavior of different chromosome races in six Paspalum species. J Hered. 1989;80:24-8.

11. Quarín CL, Norrmann GA. Interspecific hybrids between five Paspalum species. Bot Gaz. 1990;151:366-9.

12. Weihmüller E, Beltrán C, Sartor M, Espinoza F, Spampinato C, Pessino S. Genetic response of Paspalum plicatulum to genome duplication. Genetica. 2014. doi:10.1007/s10709-014-9769-2.

13. Allem AC, Valls JFM. Recursos Forrageiros Nativos do Pantanal Matogrossense. il. (EMBRAPACENARGEN, Documentos, 8). Brasília: EMBRAPACENARGEN; 1987. p. 339.

14. Pozzobon MT, Valls JFM. Caracterização citogenética em acessos de germoplasma de espécies brasileiras de Paspalum (Gramineae). In: Encontro Internacional sobre melhoramento genético de Paspalum. Anais., Nova Odessa. Nova Odessa: Instituto de Zootecnia; 1987. p. 73-8.

15. Chase A. The North American species of Paspalum. Contributions from the U.S. National Herbarium. 1929:28:1-310.

16. Oliveira RC. O gênero Paspalum L., grupo Plicatula (Poaceae: Paniceae), no Brasil. In PhD thesis. Universidade Estadual de Campinas; 2004.

17. Cidade FW, Vigna BB, de Souza FH, Valls JF, Dall'Agnol M, Zucchi Ml, et al. Genetic variation in polyploid forage grass: assessing the molecular genetic variability in the Paspalum genus. BMC Genet. 2013;14:50. doi:10.1186/1471-2156-14-50.

18. Doyle JJ, Doyle JL. A rapid DNA isolation procedure for small quantities of fresh leaf tissue. Phytochem Bull. 1987;19:11-5.

19. Billotte N, Lagoda PJL, Risterucci AM, Baurens FC. Microsatellite-enriched libraries: applied methodology for the development of SSR markers in tropical crops. Fruits. 1999;54:277-88.

20. Temnykh S, DeClerck G, Lukashova A, Lipovich L, Cartinhour S, McCouch S. Computational and experimental analysis of microsatellites in rice 
(Oryza sativa L.): frequency, length variation, transposon associations, and genetic marker potential. Genome Res. 2001. doi:10.1101/gr.184001.

21. Untergasser A, Nijveen H, Rao X, Bisseling T, Geurts R, Leunissen JA. Primer3Plus, an enhanced web interface to Primer3. Nucleic Acids Res. 2007;35:W71-4.

22. Creste $\mathrm{S}$, Neto AT, Figueira A. Detection of single sequence repeat polymorphisms in denaturing polyacrylamide sequencing gels by silver staining. Plant Mol Biol Rep. 2001;19:299-306.

23. Mateescu RG, Zhang Z, Tsai K, Phavaphutanon J, Burton-Wurster NI, Lust $G$, et al. Analysis of allele fidelity, polymorphic information content, and density of microsatellites in a genome-wide screening for hip dysplasia in a crossbreed pedigree. J Hered. 2005;96:847-53.

24. Tessier C, David J, This P, Boursiquot JM, Charrier A. Optimization of the choice of molecular markers for varietal identification in Vitis vinifera $\mathrm{L}$. Theor Appl Genet. 1999;98:171-7.

25. Pritchard JK, Stephens M, Donnelly P. Inference of population structure using multilocus genotype data. Genetics. 2000;155:945-59.

26. Evanno G, Regnaut $\mathrm{S}$, Goudet J. Detecting the number of clusters of individuals using the software STRUCTURE: a simulation study. Mol Ecol. 2005;14:2611-20.

27. Earl DA, vonHoldt BM. STRUCTURE HARVESTER: a website and Program for Visualizing STRUCTURE Output and Implementing the Evanno method. Conserv Genet Resour. 2012. doi:10.1007/s12686-011-9548-7.

28. Jakobsson M, Rosenberg NA. CLUMPP: a cluster matching and permutation program for dealing with label switching and multimodality in analysis of population structure. Bioinformatics. 2007. doi:10.1093/ bioinformatics/btm233.

29. Ramasamy RK, Ramasamy S, Bindroo BB, Naik VG. STRUCTURE PLOT: a program for drawing elegant STRUCTURE bar plots in user friendly interface. SpringerPlus. 2014. doi:10.1186/2193-1801-3-431.

30. Jombart T, Devillard S, Balloux F. Discriminant analysis of principal components: a new method for the analysis of genetically structured populations. BMC Genet. 2010;11:94.
31. Allendorf FW, Hohenlohe PA, Luikart G. Genomics and the future of conservation genetics. Nat Rev Genet. 2010. doi:10.1038/nrg2844.

32. Botstein D, White RL, Skolnick M, Davis RW. Construction of a genetic linkage map in man using restriction fragment length polymorphisms. Am J Hum Genet. 1980;32:314-31.

33. Killeen TJ. The grasses of Chiquitania, Santa Cruz, Bolivia. Ann Mo Bot Gard. 1990;77:125-201.

34. Cidade FW, Souza-Chies TT, Batista LAR, Dall'agnol M, Zucchi MI, Jungmann $\mathrm{L}$, et al. Isolation and characterization of microsatellite loci in Paspalum notatum Flüggé (Poaceae). Conserv Genet. 2009;10:1977-80.

35. Cidade FW, Souza-Chies TT, Souza FHD, Batista LAR, Dall'Agnol M, Valls JFM, et al. Microsatellite loci for Paspalum atratum (Poaceae) and crossamplification in other species. Am J Bot. 2010;97:e107-10.

36. Santos JCS, Barreto MA, Oliveira FA, Vigna BBZ, Souza AP. Microsatellite markers for Urochloa humidicola (Poaceae) and their transferability to other Urochloa species. BMC Res Notes. 2015;8:83.

37. Ferreira RCU, Cançado LJ, Valle CB, Chiari L, Souza AP. Microsatellite loci for Urochloa decumbens (Stapf) R.D. Webster and cross-amplification in other Urochloa species. BMC Res Notes. 2016;9:152.

38. Oliveira RCD, Valls JFM. Novos sinônimos e ocorrências em Paspalum L (Poaceae). Hoehnea. 2008;35:289-95.

39. Zuloaga FO, Morrone O. Paspalum. In: Zuloaga FO, Morrone O, Davidse G, Filgueiras TS, Peterson PM, Soreng RJ, Judziewicz EJ, editors. Catalogue of new world Grasses (Poaceae): III. Subfamilies Panicoideae, Aristidoideae, Arundinoideae, and Danthonioideae, Contr. U.S. Natl. Herb. Washington D.C.: Smithsonian Institution; 2003. p. 443-527.

40. Takayama SY, Freitas PM, Pagliarini MS, Batista LAR. Chromosome number in germplasm accessions of Paspalum (Plicatula group) from different regions in Brazil. Euphytica. 1998;99:89-94.

\section{Submit your next manuscript to BioMed Central and we will help you at every step:}

- We accept pre-submission inquiries

- Our selector tool helps you to find the most relevant journal

- We provide round the clock customer support

- Convenient online submission

- Thorough peer review

- Inclusion in PubMed and all major indexing services

- Maximum visibility for your research

Submit your manuscript at www.biomedcentral.com/submit
() Biomed Central 